\title{
Mediterranean households, British colonial statistics and Greek insular landscapes: insights from 19th century Antikythera
}

\author{
A. Bevan and B.R. Hassett
}

Manuscript copy for:

Bevan, A. and Hassett, B.R. 2019. Mediterranean households, British colonial statistics and Greek insular landscapes: insights from 19th century Antikythera, Continuity and Change 34.3: 349-373 (doi:10.1017/S026841601900033X)

\begin{abstract}
This paper addresses a 250-year episode of human colonisation, community growth and subsequent decline on the small Greek island of Antikythera (AD 1770 to present), focusing on rich documentary sources from four decades of British rule in the early 19th century. In particular, a series of nominal censuses and accompanying agricultural statistics can be combined with intensive landscape archaeological survey evidence to explore evidence for changing 19th century households, household economies and how these are manifest across an entire physical landscape. We also contextualise this well-recorded, most recent historical episode within the island's deeper population history stretching back at least seven millennia.
\end{abstract}

\section{Introduction}

Mediterranean family structure, population density and economic life have long been a focus of interest across several academic subject areas. In anthropology and sociology, for example, marriage age, neolocality, birth spacing and household composition have all been parameters invoked in wider disciplinary debates about the coherence (or not) of the Mediterranean as a social analytical unit. In archaeology, demographic reconstructions have always been difficult given the chronologically fuzzy, palimpsest nature of the material record, with demographic modelling swinging in and out of favour over several academic 
generations. Studies of the small-scale demographics of households and communities (rather than large-scale studies of continental population displacement) have been especially rare in archaeology, even though researchers have long recognised the likely underlying importance of such parameters for explaining changes in archaeological site size and site duration, dwelling form and household equipment, artefact assemblage diversity, landscape capital investment and many other features of the surviving record.

There remains a cross-disciplinary need to grapple with the relationship between population dynamics, family structure, household economies and community-scale landscapes in the Mediterranean over shorter and longer time-scales, and in both urban and rural or marginal settings. This paper seeks to make a contribution to addressing these challenges via archival evidence from the small Greek island of Antikythera, bringing together insights from (a) demographic analysis of nominal-scale censuses spanning from $\sim 1814$ to 1848 , (b) further archival attention to an unusually rich range of additional statistical information collected during the British colonial occupation, (c) attention to the physical traces of this 19th century episode of human habitation across the Antikytheran landscape, and (d) a much longer-term view of the island's population dynamics provided by intensive archaeological survey. In section 2, before looking at the detail of the Antikytheran setting and evidence, we discuss the wider research context provided by existing studies of Mediterranean historical demography, and the attention paid so far to Greece.

\section{Perspectives on Mediterranean Demography}

Family structure, family life-cycle, tenure and inheritance systems, household and service economies, and population change (as well as related issues such as concepts of female honour), have been central to debates about cross-regional generalisation in Mediterranean anthropology, demography and sociology for decades, prompting vociferous assertions of a general unity of social practice across large parts of the Mediterranean on the one hand, and 
equally vociferous counter-arguments for regional variation. ${ }^{1}$ For example, Hajnal drew a contrast between what he argued was a globally and historically unusual pattern seen in western Europe (in better documented periods since about the 16th century AD) of comparatively high age at marriage, a high proportion of individuals that never marry and lower overall fertility/mortality, and an eastern and Mediterranean European pattern involving earlier marriage age (especially for females, with many married by 20 years old), near universal marriage and higher overall fertility/mortality. ${ }^{2}$ Laslett and colleagues ${ }^{3}$ argued that, whilst it might be appropriate to adopt the nuclear family as a kind of demographic nullhypothesis, exceptions were not hard to find and Mediterranean Europe was possibly one such, where more complex family structure had regularly prevailed, with subsequent work further emphasising the lesser importance of neolocal residence and low numbers of non-kin servants living within Mediterranean households compared to northern European examples. ${ }^{4}$

Despite a strong subsequent backlash to such views using both case studies demonstrating great regional variability in Mediterranean family structure ${ }^{5}$ and studies demonstrating a lack of consistency in north-western European comparisons, ${ }^{6}$ certain interesting patterns persist. Reher, for example, reaffirmed the general principle that there were indeed macro-regional differences in family life in historical times between north and south Europe. However, he suggested a more important distinction had to do with the relative emphasis placed on family ties in general (rather than family co-residential structure). Reher argued that lifecycle service, where adult individuals left the family home for a period of time as non-kin, live-in servants for other families was a diagnostic characteristic in northern Europe (Viazzo characterized this as a kind of delayed neolocality). In much of southern Europe adults individuals were more likely to leave the family home as married couples. ${ }^{7}$ Indeed, as Goody noted ${ }^{8}$ census-takers simplify complex co-production, co-residential and family headship making simple 'family structure' a fairly problematic index in the first place, and making those European/Mediterranean distinctions built upon it alone equally problematic: 
"[t]he fission of the household, the housekeeping unit, is linked to the fission of other domestic groups. The new family may occupy a separate house or dwelling unit ("houseful"), it may start its own distinct productive unit ("farm family"), or it may simply establish its own consumption or housekeeping unit ("household"). All these distinctions have to be graded. Closely related persons tend to live in adjacent houses, and they continue to enter into complex relationships even after residential fission has taken place. ... [W] hat would make more of a difference is not so much fission into separate households or housefuls, as the intervention of spatial mobility, movement to another settlement, the scattering of kin."

An early springboard for the study of human demography in Greece was provided by Valaoras, starting in the $1930 \mathrm{~s} .{ }^{9}$ Since then regional specialists have emphasised both the extreme heterogeneity exhibited by population and family structural trends across different parts of Greece, and the confounding effect of the very patchy statistical windows provided on Greek populations during the 19th and earlier 20th centuries. The latter patchiness is driven by Greece's multiple episodes of colonial rule, administrative records and sociopolitical interventions made by several different countries, the slowly expanding geographical footprint of the Greek nation-state itself, the disruptions caused by both internal civil and external international strife, and differential preservation of relevant archives into the present. Consequently, the study of Greek historical demography has been understandably patchy and opportunistic, and has been taken forward via a mix of quantitative and qualitative observations.

Greece, like other areas of the world, experienced a dramatic demographic transition in the latter part of the 19th and 20th centuries, as overall mortality risk fell significantly and the cause of most deaths switched from contagious to degenerative disease, and more 'natural' fertility profiles gave way to ones indicating a greater role for increasing fertility control 
(mainly during the early 20th century). ${ }^{10}$ In line with this, several studies suggest that Greek islands experienced lower infant mortality (and thereby greater life expectancy at birth) than the Greek average from at least the latter part of the 19th century until the mid-20th century. ${ }^{11}$

Caftanzoglou's study ${ }^{12}$ of Epirote families suggested a pattern in step with the wider models with early age at marriage, a large average marital age gap (e.g. 7 years), an absence of non-kin in households as servants, no clear evidence for individuals who never marry, and inheritance norms that did not usually encourage newlyweds to establish a new residence, but rather to remain close to the groom's parents' household. ${ }^{13}$ Hionidou comments on similar patterns of early marriage age for females and prevalent nuclear households on Mykonos in later 19th and earlier 20th century AD in comparison to those observed in southern Italy and southern Portugal. ${ }^{14}$ Caftanzoglou makes at least three further comments of possible consequence for Antikythera in emphasising, first, an obvious but important point that the prevailing household structure observable in any given community might cycle through different evolutionary states through time, without any exogenous social or economic influence, as for example a more evenly nuclear pattern gave way to more extended families as heads of household grew older, but did not as yet pass on property in full. Secondly, there were distinct regimes for households in one Epirote village that was largely pastoralist (where more complex co-residential structures were favoured, at least in better times), and those in a more agricultural village (where de facto simpler households often predominated due to long periods of male absence for seasonal work). Finally, the census taker played a major role as an interpreter of various de facto and de jure family residential relationships (and of local versus foreign domicile) which urges caution in interpreting the archival evidence. Forbes reinforces Caftanzoglou's last point in an ethnohistorical study of families on 19th century Methana in which new couples often built houses adjacent to the groom's parents' home, and lived separately but worked 
cooperatively, often calling themselves a single 'family' at least until the death of the parents. ${ }^{15}$

Furthermore, it is worth noting that the marriage/migration patterns of Greek islands may have been driven by very different social structures than those of mainland Europe in the same period, just as the demography of islands worldwide typically must be treated as a related but special case of mainland dynamics. For example, observations of 19th century marriage patterns suggest that Greek island communities more frequently followed a pattern of uxorilocality, moving into the home of the wife upon marriage, than those on the mainland or elsewhere in the Greek-speaking world. ${ }^{16}$ This has been suggested to be a result of the importance of wage labour for island economies, led by male economic migration into seasonal agricultural, seafaring, or similarly itinerant labour. The extent to which itinerant labour, or more directly the removal of younger men from the demographic pool of an island, affects the marriage age of women and subsequent fertility rates, is a question that deserves consideration. Research into migration patterns on the island of Mykonos shows that a strong trend of 'circular' migration existed in the 19th century, where working-class males took seasonal or longer itinerant employment at sea, in Athens, Piraeus and the port cities of nearby nations; and both men and women migrated to work in service or apprenticeships on larger nearby islands. ${ }^{17}$ To summarise both for the Greek and wider evidence, the underlying mechanisms behind household structure may include both the inheritance and migration patterns mentioned above, but ultimately manifest a demographic system dictated by fertility and mortality. Szoltysek nicely captures the way demographic factors ultimately influence household structure regardless of the participation in labour or other markets, describing the constraints on household structure imposed by an essentially low fertility, high mortality regime and led by late age at marriage. ${ }^{18}$ In short, in societies where people marry late, there is a decreasing likelihood that they will have any surviving parents to cohabit with.

\section{Setting}


Antikythera is a small, limestone island of some 20.8 sq.km (figure 1a), with a modern yearround population of just 34 inhabitants in the 2011 census, who are mostly retired and/or engaged in non-agricultural, non-industrial activities. And yet despite this very light human footprint today, the island also demonstrates a longer history with repeated cycles of occupation by several hundred people (figure 1b), multiple villages and considerable agricultural investment. Lying about 30-35 km away from the nearest larger land masses of Kythera to the north and western Crete to the south, Antikythera is often deemed remote in Mediterranean terms, albeit certainly not so when viewed in a globally-comparative island perspective. Moreover, despite its reputation as a Mediterranean isolate, it sits in the midst of a historically well-known maritime thoroughfare articulating not only movement between the central Mediterranean, Ionian and Adriatic Seas to the west and the Aegean and Levant to the east, but also north-south between Libya, Crete, the Peloponnese and the Adriatic coasts. Its role on this cultural and geographic interface is visible archaeologically in flexible cultural affiliations (e.g. local material culture such as pottery may be more similar to that in western Crete in certain chronological periods, and to that in Kythera or other parts of southern Greece in others, probably reflecting wider changing patterns of travel and social interaction) over a period of at least 7000 years of definite human presence. It acted as a stopping place for what appear to be early hunting (and perhaps raiding) groups from the Argo-Saronic gulf in the later Neolithic, played host to Cretan ('Minoan') farming communities during the Bronze Age, offers good evidence that it was a fortified pirate stronghold in the Hellenistic and clearly supported a series of Late Roman and Middle Byzantine/Early Venetian villages. In between these episodes were periods of likely abandonment (at least in terms of full-scale, permanent communities) for several centuries at a stretch (for greater detail, see Figure $\mathbf{1 b}$, and the primary publication of the archaeological survey ${ }^{19}$ ). The most recent cycle of resettlement is one that began around 1770 by families from western Crete, leading to a relative population boom in the early 19th century before a gradual decline over the 20th century. It is with an eye to this wider context of repeated expansion and collapse 
that we have gathered documentary data on this last population cycle, where triangulation of different lines of evidence is particularly compelling.

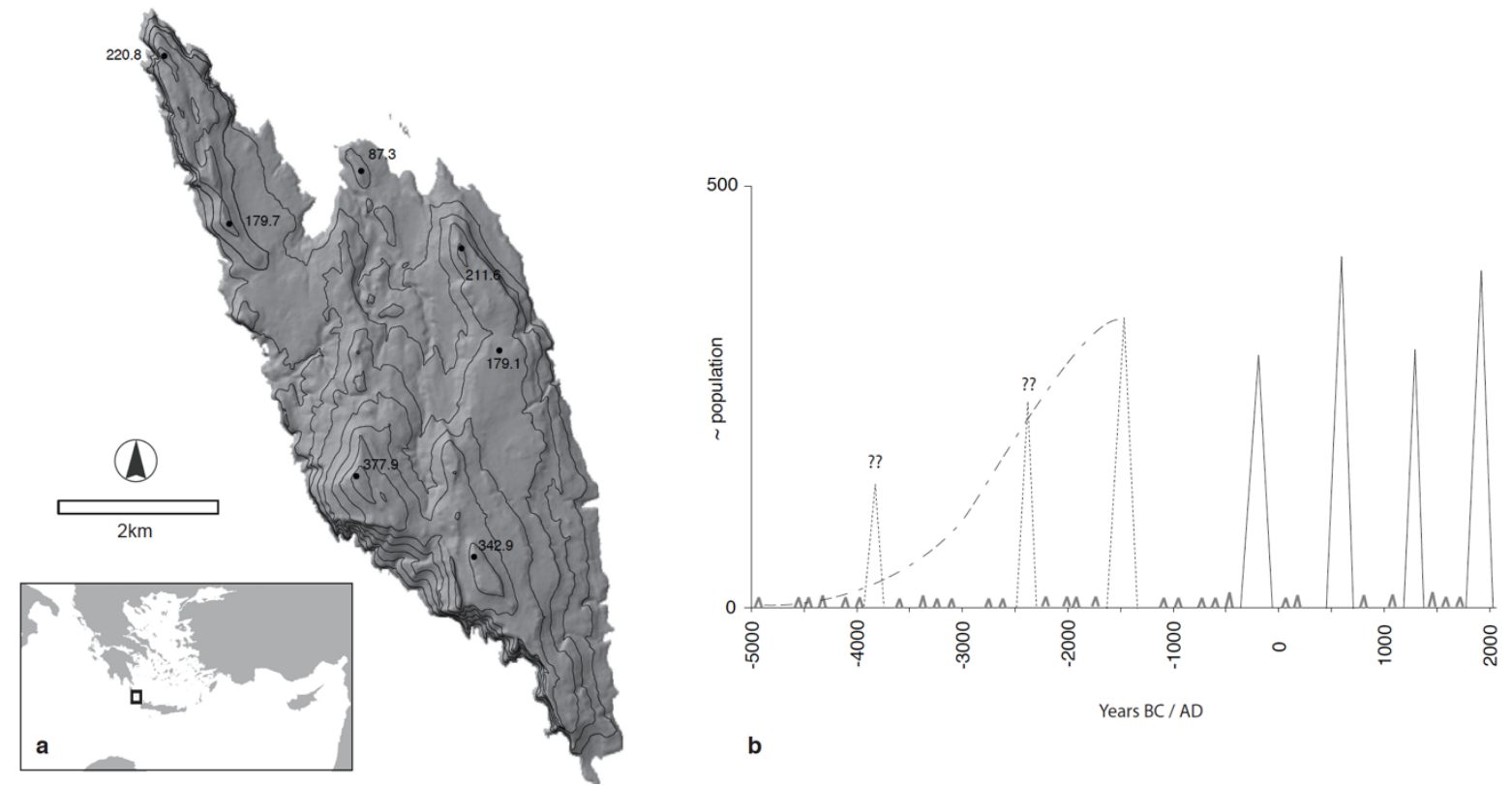

Figure 1. (a) Location of map of Antikythera and its wider Aegean and eastern Mediterranean setting (elevation contours are in 50m intervals mASL), (b) inferred long-term population trends. For earlier periods, the diagram is marked with '??', as intensive archaeological survey demonstrates several major periods of prehistoric agricultural habitation, but without certainty about whether occupation was continuous or discontinuous. Some degree of discontinuity in prehistory is likely however in line with that observed in the historical era.

The history of the Greek islands in the south-western Aegean and lonian seas is very much one of political and cultural contingency, both when viewed over the last of 400 years or so of better preserved documentary history, as well as over the longer term. Focusing first on the former more recent historical periods, Crete, Kythera, Antikythera and the Ionian islands were made possessions of the Venetian Republic from AD 1204 after the Fourth Crusade. Crete was then the setting for considerable Venetian-Ottoman confrontation before finally and fully being annexed by the latter in 1669. During the 18th and 19th century, the rest of this south-western insular set, increasingly known as the lonian islands, were passed back and forth between several different major powers. Kythera and Antikythera were part of the Venetian Republic up until 1780 (with a brief interlude of Ottoman control 1715-18), then 
controlled by France (1780-1798 and 1807-1814), Russia and the Ottoman Empire (17981807), Britain (1814-1864) and thereafter the independent Greek state. The identity of these two islands as 'Ionian' was geographically eccentric but politically expedient as the most southerly of Venice and subsequent French, Russo-Ottoman and British possessions and border zone with Ottoman Crete. One side effect of this complex political history over nearly a century was a set of complicated population flows both east-west and north-south, with for example the recolonisation of Antikythera by families from Crete, local island labour forces moving seasonally between Kythera/Antikythera and both the Peloponnese and Smyrna in Anatolia, as well as important local ruptures such as the peasant revolts against noble control on Kythera. ${ }^{20}$

Both a general emphasis on careful resource-inventorying during these successive political handovers of Ionian island sovereignty and an especially acute 'statistical fever' sweeping British colonial practice in the early 19th century provided the catalyst for expansive registers, ${ }^{21}$ beginning in the Venetian period for certain islands like Kythera, but on Antikythera records focus on the British period and are mostly preserved today in the UK National Archives (Colonial Office section, located in Kew Gardens, London; here abbreviated as TNA) and the Historical Archive of Kythera (located at Chora, Kythera; here abbreviated as TAK). We further outline some of the detail of the records below, but here it is worth noting that the aggregate population statistics for Antikythera delineate the general picture of a very clear rise and fall of population over about 250 years. Following the recolonisation by Cretan families around $A D$ 1770, there was a semi-stable base population of 200-300 permanent residents for many decades, followed by an increasingly rapid decline in the 20th century.

\section{Antikytheran Family Reconstruction}

\subsection{Demographic Source Data}


Archival records that include the age, surname, and important vital statistics such as registration of marriage or death offer unusual access to otherwise difficult-to-estimate demographic data, especially relating to fertility and mortality risk (e.g. age at marriage, number of children per woman, and survival rates). For Antikythera, birth, marriage and death registers made for several different Antikytheran parishes by local priests survive for the early 19th century (digital scans via the Greek General State Archives, http://arxeiomnimon.gak.gr), but they are often hastily handwritten documents preserved only partially, and with various abbreviations for the naming of individuals. Because of these limitations, we do not use these sources. ${ }^{22} \mathrm{~A}$ core focus below is instead on three nominal censuses from $\sim 1814,{ }^{23} 1840$ and 1845 that recorded the population of Antikythera with complete names and ages, supplemented by a further census from 1825 that only named household heads with counts of male/female adult and children. One of the obvious strengths in using multiple nominal censuses is that we can better understand structural change and mitigate the risk that any single census is an unrealistic snapshot of households at specific moments in their life cycle. ${ }^{24}$ The 1825 summary document is also extremely useful in recording, by ascribed household, a large influx of refugees at the height of the Greek War of Independence. These censuses were collated by the Antikythera local governmental representative, with the aid of primary collections seemingly often made by island priests, before being submitted to the British authorities on nearby Kythera and eventually synthesised for British Colonial Office purposes across multiple lonian islands. Hence, there are partial written documents in Greek that were usually consolidated into a more definitive version in Italian by the island representative and eventually summarised in English. In addition to these censuses, we introduce some complementary insights offered by a longer series of population totals for the island (ca.1770-2001) and early 19th century summaries of the island's agricultural production.

\subsection{Summary Demography}


For much of the $18^{\text {th }}$ century Antikythera appears to have been uninhabited and uncultivated, but a combination of 'years resident' information in the $\sim 1814$ census (of which the maximum is 34 years), along with a mention of the colonisation event in later petitions to the British governor on Kythera suggest it was recolonised sometime in $1775-1780 .{ }^{25}$

Early population estimates over the next few decades are scarce and informal, but from $\sim 1814$ onwards full or summary censuses suggest both population instability due to the arrival of refugees and temporary residents, but also considerable internal growth. 151 of 191 residents were native born in 1814 (79\%). By 1845, 316 out of $372(85 \%)$ named inhabitants were classed outright as 'indigenous', with the remaining 56 named as foreign, from Crete or Kythera. This latter group is clearly a malleable 'non-resident' category, including individuals from the ages of 19 to 88 who have evidence of prior association with Antikythera for between 2 and 60 years, and are recorded both as currently on- and offisland. Although such behaviours of flexible domicile, origin and travel are far from unique to small Greek islands, we will argue in more detail below that they are important features of Antikytheran households.

These variable levels of in- and out-migration on Antikythera make it impossible to attribute absence on a census record to mortality alone, so for the purposes of this paper island mortality must be estimated using regional comparators. Similarly, without full birth registers and with the high likelihood of older sons and daughters participating in an off-island economy and remaining uncounted, it is not straightforward to calculate rates of female fertility, but what we can establish is a snapshot from the census data of individual household structures. The resident population of the island expanded from 170 to 276 'present' residents in the years between $1811 / 14$ and 1845 , (a growth rate of $\sim 62 \%$ ). Hoinidou (2002) suggests that for the island of Mykonos there was no shift in mortality until around the 1930s, and while we have no registers to support this on Antikythera, it is unlikely that sanitation or other external circumstances materially changed the island's mortality rate 
in this period. Given this and the decline in migration, Antikytheran demography in this period seems likely to have experienced an increase in population-level fertility.

The drivers of individual-level fertility are age at marriage, age at first birth, levels of nonmarriage and mortality. We estimate these values from the two census. These are necessarily rough estimates, because it is very difficult to accurately measure fertility when individuals cannot be traced through multiple iterations of the census due to shifts in the level of detail of recorded names, particularly for household dependents, and we use the total number of children recorded as present in the household to suggest the total number of births to the wife. The most important of these factors is likely that older children have already departed the household through migration, marriage, or death. We refer to 'fertility' throughout the remainder of the paper, but it must be borne in mind that these are estimates minus the effects of mortality which would have eliminated a good number of children from appearing in the census. We estimated women's age at first birth by subtracting the age of her oldest child from the mother's age. To estimate age-at-marriage we assume a one-year gap from the marriage to the birth of the oldest child. Here, there are obviously methodological problems, ranging from the potential that children were conceived out of wedlock, that conception was not immediate upon marriage, or that the first born child will have departed the household at the time of the census.

Keeping these caveats kept in mind, for Antikythera there is evidence of near-universal and early marriage in the $\sim 1814$ census. Rates of non-marriage for women were low: there were few unmarried older women documented (2 of 66, one listed as a 'daughter') or older unmarried daughters (all were less than 23 years of age. Our estimate for average age at marriage for women at ca.20 years is relatively young (with men marrying at ca.30 years). On average Antikytheran women at this census were at 20.9 years old at first birth (median: 19 years). The average number of children in a cohabiting family in $\sim 1814$ is 4 . Antikythera 
in 1814 fit closely with traditional models of a 'southern', 'Mediterranean' demographic pattern of high fertility, high mortality, and early household formation.

By 1845 , we arguably see an altered set of these culturally-influenced factors with the potential to act on island fertility. ${ }^{26}$ The average age-at-marriage remains nearly identical (females ca.19 years and males 29), but marriage had ceased to be a near-universal experience for women. There is a slight increase in potential lifetime-celibate women between the censuses. In the 1845 census there were three likely lifetime-celibate women: two over 50 listed as 'di solo' and one described as a sister, and four unmarried women over 40. Male lifetime celibacy is not easily understood via the census data here, given married women's fathers' or family names are not generally recorded, and given the potential for non-resident families to be poorly or inaccurately accounted for.

For understanding family structure, we adopt Hammel and Laslett's well-known classification ${ }^{27}$ to break down co-location of related individuals into broad categories of more or less nucleated households, but given that this classification system has been criticised from a variety of perspectives, ${ }^{28}$ have also tried to supplement it with attention to the coresidential patterns of the elderly cohort. A further point to note is that this scheme anticipates a kind of written, almost autographic, proof of household structure (e.g. as recorded by the group for the group) or at least a grounded cultural understanding of local family context: overall, this is largely the case on Antikythera in our view, with both local priests and the island representative drawing up the main lists, but it remains possible that the external schema of the colonial authority (e.g. for taxes, forced labour requirements, domicile criteria etc.) have intruded in obfuscatory ways. One visible instance where the divergence between structural views of family constitution between Antikytherans and the colonial powers is in the additional soprannome in the 1845 census. These family 'nicknames', were probably useful in delineating branches or lineages in a landscape dominated by relatively few patronyms. The multi-tiered familial reckoning indicated by use 
of a soprannome would have been easily understood by the Italian-speaking island representative, but not regularly used as part of official British record keeping. Unlinked surnames appearing under the same soprannome may also indicate common descent, such as the sopraname 'Cochino' which is recorded for both for a single nuclear household of the Cazzaneva family and two elderly sisters (probably the aunts of the head of the Cazzaneva household) living in a daughter's house with her children.

There are clear divergences in the patterns of family structure between the island's own longer-term residents (Table 1) and the refugees who began to arrive under British protection in the 1820 s. The abbreviation of the census recording in 1825 to only a simple count of adult and juvenile males and females for each family unit restricts comparability to some degree. This is unfortunately because the 1825 census had the largest influx of refugees in surviving records. The large number of widows with children among the refugees in 1825 is unsurprising, but the 34 resident households of widows with children is; it is unclear from the historical documentation whether either seasonal or conflict-related activities may have temporarily affected household structure on Antikythera in 1825 or whether this reflects some degree of resettlement, discussed in the next section.

\subsection{Migration and its Consequences}

A further key feature of the mix of more and less detailed $19^{\text {th }}$ censuses from Antikythera that is critical for interpretation of island life is the mention of entire families, with names, ages, and taxable assets, where the family is marked as 'absent'. These families are clearly identifiable by name, sometimes a soprannome, and presence through multiple registers as Antikytheran. Their households are officially recorded alongside their physically-present neighbours, and there is no suggestion that 'absent' Antikytherans are not a functional part of island demography, at least according to census officials. The repeated counts of households 'present' or 'absent' provide very useful insight into the structure of lonian mobility, allowing unparalleled insight to the age, sex, and kinship structure of the cohort of 
islanders potentially participating in seasonal or temporary migrations. Named professions given in the 1840 and 1845 censuses help here, too. Farmers are the most common occupation as expected, but also included were the island representative (or primate), priests, ships captains and sailors, shoemakers, a schoolmaster, school students, midwives and a dyer. Only one servant is identified directly in any of the census (a 12-year old boy in the extended household of the main priest of the island). Often whole families were assigned the head of household's profession while they might have been expected to have taken on other categories of work as individuals.

Population movement within the turbulent political and economic ecology of the Ionian islands in the 19th century is harder to capture, though we can use the intermittent presence and absence of islanders during each census to build a very partial picture of itinerancy. It is unclear from the census records themselves how many of the 'absent' Antikytherans were expected to return to the island although occasionally marginalia are insightful: for example, a side note for the Aloisio family in 1845 stipulates the land holdings of two brothers are unsold, despite the brothers and their families having left the island. There is a considerable shift in patterns of non-residence from $\sim 1814$ to 1845 , with 21 of the 191 islanders marked as 'absent' (11\%) in $~ 1814$ and more than double that percentage in 1845 . Much of this marked shift is attributable to the addition of women to the category of absent islanders (figure 2); while there were no women marked as absent in $\sim 1814$, there are 38 females and 58 males listed in 1845. Many of these may have been dependents as they are listed as wives or daughters in the census, but this in itself is interesting in implying that entire family units, many with agricultural holdings, had departed the island. 

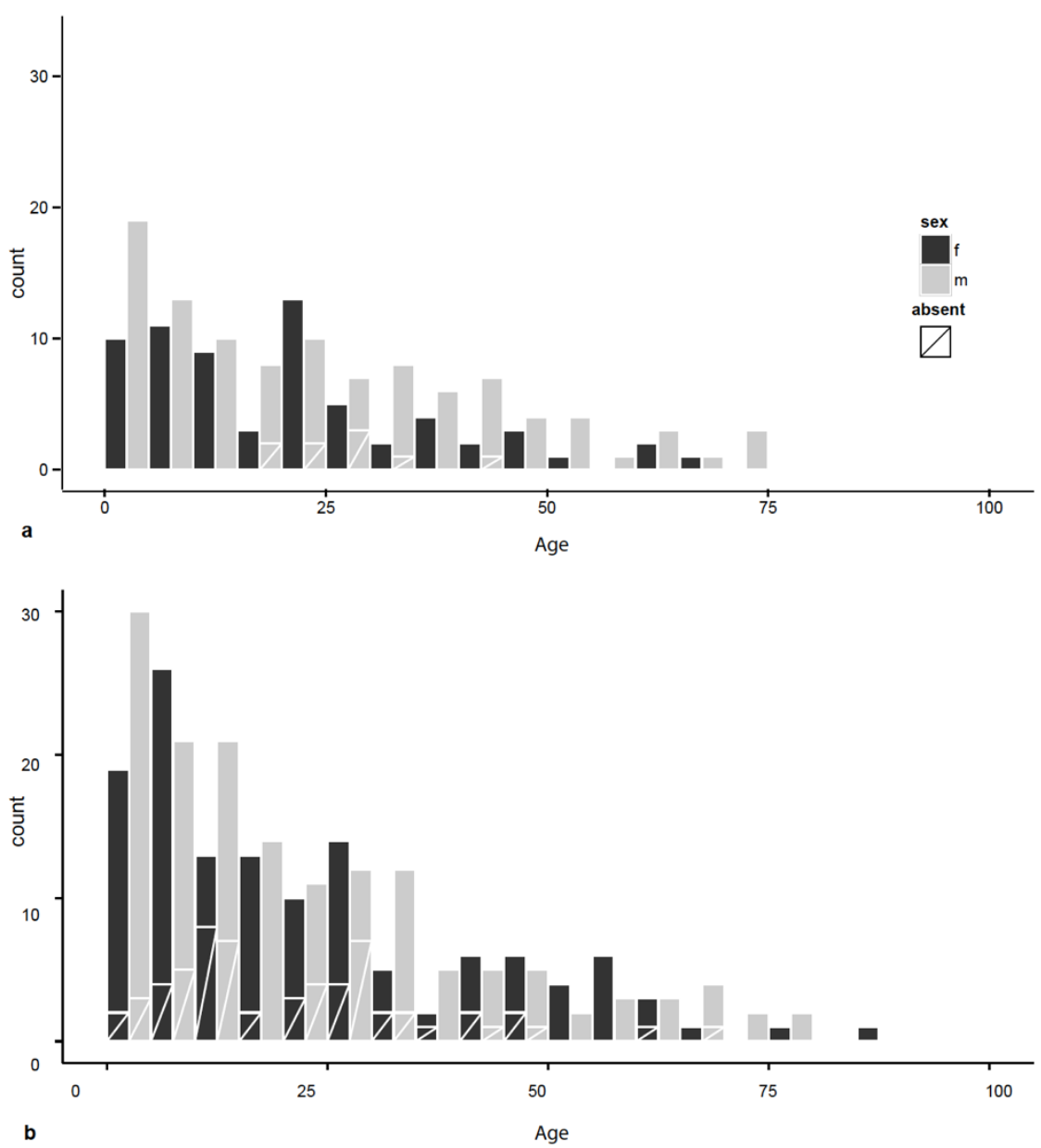

Figure 2. Age categories in (a) 1814 and (b) 1845.

The wider context for these movements is a strong pattern of circular migration amongst Greek island communities in the 19th century (and indeed before and after), especially amongst young males, almost all of whom participated in such seasonal ventures off-island as a way to make a financial start in their lives. ${ }^{29}$ There was a general preference for coastal port towns along the Greek, Turkish and Russian coasts, with Kythera, Smyrna, Hermopoulis, Crete and Monemvasia prominent amongst others in the Antikytheran archives. ${ }^{30}$ As Hionodou notes for Mykonos, ${ }^{31}$ '[c]learly the sons of those possessing large plots of land were more likely to become farmers themselves. Still, becoming a farmer could be the end result of years of temporary migration, sailing or circulation, that would enable the accumulation of enough wealth to purchase land and to convert into a farmer either the property-less wage earner or the owner of a small plot of land.' A good example amongst 
many on Antikythera might be Gio Carcali, who was listed as a sailor in the 1840 census and as a farmer in $1845 .^{32}$ In any case, seasonal circulation was a risk-buffering exercise, a way to explore priorities for permanent emigration off-island and/or a way to handle issues of onisland tenure, partible inheritance, etc.

Large scale population movements throughout the eastern Mediterranean region are in no way a new phenomenon, and go back to the Neolithic if not before (as shown in Table 1). The records from Antikythera provide a remarkable snapshot of the mass refugee movement towards the end of the Greek War of Independence, and the demographic impact on an insular community of a tenfold expansion of population in a matter of years, if not months. Refugees were clearly arriving on both Kythera and Antikythera from the earliest phases of the war, not least because of the perceived protection offered by British rule of these islands. ${ }^{33}$ However, the best documentary evidence comes from the 1825 register of household-level population counts that record the number of Antikytheran resident and refugee families. As was discussed above, families are simply described along with a named head-of-household and counts of other adults and children by gender. While full classification according to the Hammel-Laslett system is hindered by this lack of specificity -it is not clear if multiple adult females in a family indicate cohabiting mothers and unmarried daughters, sisters, mothers and married daughters, etc. -- we can still pick out some basic indicators of whether multiple age groups are, or are not, present in each family.

Solitary households were easily identified. A series of caveats remain for the rest of the data, foremost among them being that co-residence is not specified, only family membership. It is unclear to what extent co-residence is implied for these refugees, but as there are examples of males with the same name and different family compositions, it is reasonable to assume that in this case a father and son have been recorded separately, probably indicating separate residences. Given the paucity of data, a single adult male listed with a single adult female may indicate a variety of relationships (brother and sister, etc.) but here are classified 
as a married couple with no children (Type 3a); where multiple adults of the same sex cohabiting in absence of children have been classified as co-resident siblings (Type 2a), though they may in fact be parents with adult children. Generational extension within a household is impossible to estimate without accurate ages or knowing the classificatory criteria used to determine 'adult' status.

To return to consideration of the effect of migration in terms of the influx of refugees during the crisis years of the 1820 s, unsurprisingly the picture of Antikytheran demography that emerges is remarkably different from the patterns visible on the island from non-crisis years. The most noticeable change is in the very high proportion of female-led households with children. This is clearest in the list of refugees, as might be expected in families fleeing conflicts in which the adult male of a family may have been killed or otherwise separated from the household. Several single-adult families headed by males are also evident, more among refugees than residents. Households consisting of solitary adults and multiple codocumented (and perhaps co-residential) adults with no children are unique to the refugees. A final consideration is the long-term effect of this immense refugee population on the tiny island. In 1825, the 271 resident Antikytherans were grossly outnumbered by 877 refugees (plus a further 122 'resident aliens' who may or may not have been refugees from early in the war). By 1840, however, the population was back to 280 with no sign of a further group of temporary residents from elsewhere. Despite one or two overlaps in family surnames amongst residents and refugees, the latter seem mostly without obvious family linkages on the island, and this, perhaps coupled with the rather harsh living conditions on Antikythera, may have discouraged the refugees from remaining on the island longer-term.

\section{Agricultural Statistics}

So far we have focused on what insights might arise from the surviving nominal censuses from Antikythera. However, further professional and agricultural statistics, as well as diplomatic correspondence, are also available for the island and these offer useful wider 
economic and social context. They also offer potential explanation for some of the patterns just described (e.g., the need for seasonal migration, how household structures might relate to landholdings). The main crops grown by Antikytheran families during the period of British administration were an intercropped wheat-barley mix (smigado, occasionally pure barley), a small amount of pure wheat, some oats and maize, various legumes (especially broad bean) and small amounts of grapes (mainly for locally-consumed wine), but no real investment in any familiar lonian or Greek cash crops such as olives or currants. ${ }^{34}$ This suggests that any Antikytheran family's ability to buy additional subsistence resources (e.g. olive oil) or luxuries at this time came largely from their ability to secure occasional off-island employment or bring to market small quantities of livestock. Recorded cereal yields are between 0.2 and 1 tons per hectare which are very low both compared to Kythera and other parts of Greece before the later 20th century, but not unsurprising for a very small island with only moderate quantities of fertile soil, subject to considerable sea spray, and with a small total agricultural labour force that was further reduced by seasonal off-island employment.

As noted above, the census and other summary data suggests a population rising slowly from a smaller colonising group in around 1770 to a community of several hundred people. Occasionally but fairly consistently, the island's numbers were swelled by refugees from the wider political confrontations of the time: perhaps the most salient example in the records is an influx of some 877 refugees in 1825 during the Greek War of Independence (figure 3a). A similar but much larger influx was responsible for the massive increase noted at Hermopoulos on Syros at the same time (which grew from 150 in 1821 to 13,805 people in 1828). ${ }^{35}$ It is likely given the economic and labour links between Syros and Antikythera at the time that some of the arrivals to Antikythera went to Syros first. In both cases, Syros and Antikythera were most likely under the umbrella of a foreign power (French support for the Catholic community on Syros in the one case and British administration in the other) that encouraged refugees to choose these destinations. In any case, the numbers of longer-term residents on Antikythera remained around 200-300 for some time but began to decline again 
from the middle years of the 20th century down to a year-round population of some 34 inhabitants in 2011.

Juxtaposing this historical demographic trajectory with the agricultural and livestock statistics suggests that again, at a decadal scale, we cannot correlate upward or downward shifts in raw human population with amounts of land under crop or raw quantities of livestock in a straightforward way, but rather that there might be lagged chronological effects and politically contingent factors. More precisely, the available records suggest that the amount of declared 'cultivable' land under crop rose from about a tenth to about half of total island area during the period 1811-1847, but that an abrupt increase occured in the 1830s over a decade after the observed refugee spike in population. It is possible that a temporarily larger labour force of refugees allowed land clearance and a more complex and gradual process of extensification with which was only later captured by official statistics, but it is also possible that the 1825 refugees had no impact on local agriculture (given their brief stay), but rather that the sharp increase in agricultural land was perhaps due to the British administration's incentives to bring new land into use. ${ }^{36}$ 


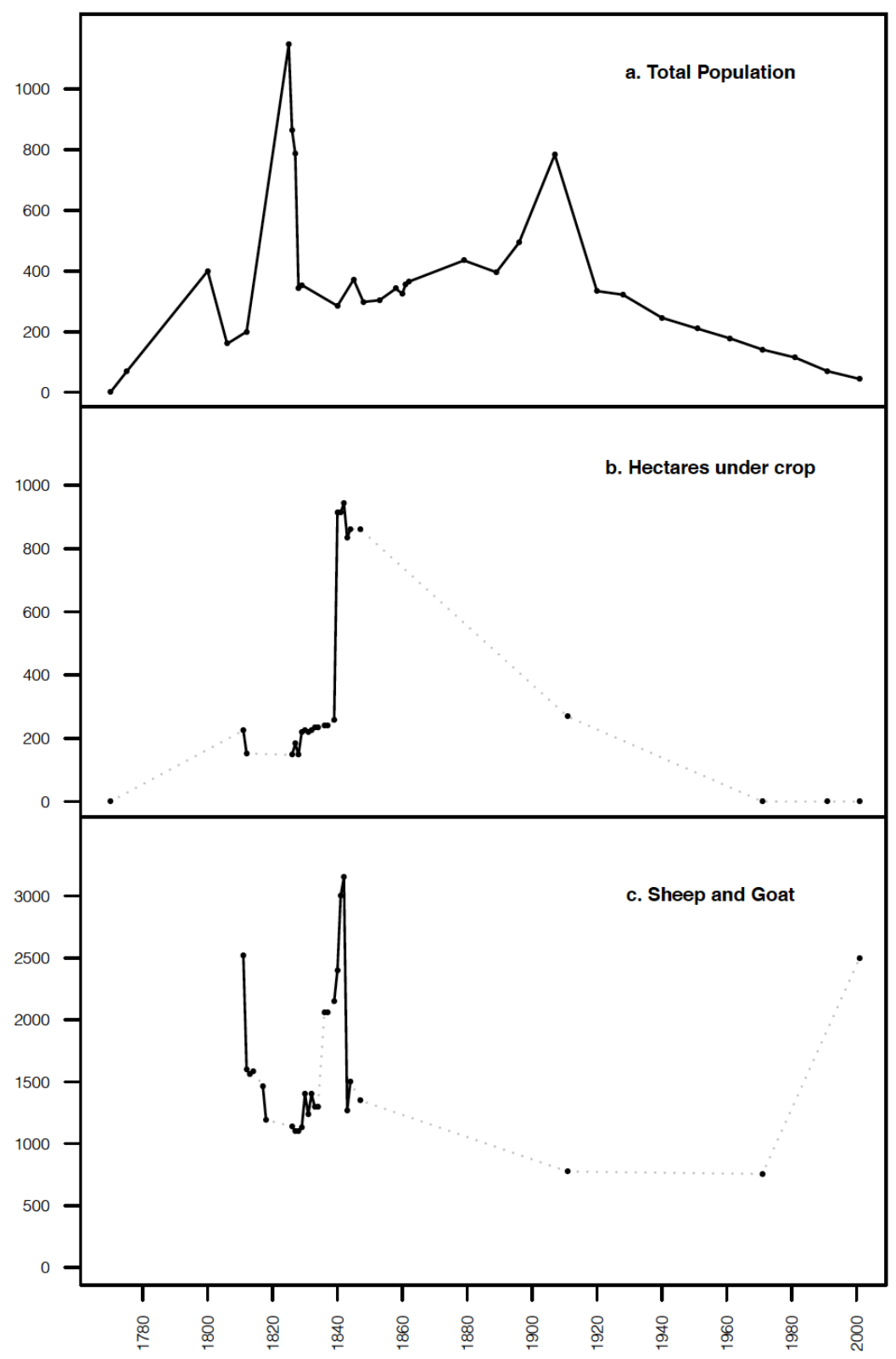

Figure 3. Demography and agriculture: (a) population from ca.1770 to present, (b) hectares under cultivation or one-year fallow (total island extent is 2080 hectares), (c) number of sheep and goat. Dotted lines cover multiple years over which annual records are unavailable. Earliest population data 1780-1810 is inferred from passing comments by certain commentators rather that systematic censuses. Sources: TNA C0136.1332-40, TAK,

National Statistical Service of Greece.

Turning to the livestock data, not many of the early records disambiguate sheep and goats or add details about other animals, but in 1811 there were 1924 goats and 592 sheep (ratio 3.25 , plus 115 cattle with no mention of donkeys or other equids). In the period covered by high-quality surviving records, $1825-1845$, there is more of a balance among sheep and 
goats as well as other animals, with for example some 1400 goats and 1000 sheep in 1840 (ratio 1.4) as well as 200 cattle and 100 donkeys. By this point, most ordinary households possessed cattle (and often a working pair for ploughing), and some families (who typically already owned plenty of other livestock) also possessed one or more donkeys. Subsequent evidence from after Antikythera became part of the Greek state is rare, but disaggregated agricultural census data from 1911, 1971 and 2001 suggest further fluctuation. Today, there are some 2000-3000 goats, but only one small flock of sheep, no cattle and one or two donkeys. Although the overall livestock evidence suggests important stochastic variation through time in herd size and type (due to disease, buying-and-selling strategies, off- and on-island transport, etc.), a pattern still emerges of goats predominating as a founder-andfallback strategy both earlier on and later on in the island community's trajectory from colonisation to growth to decline. That is, goats were both what colonists might first bring and what communities might rely more on in hard times, and were potentially negatively correlated with the proportion of land under consistent cultivation. This theoretical model is also in step with wider assumptions about population dynamics and abandoned Mediterranean 'goat islands' (as well as Antikythera's previous name which was 'Aegila' (literally 'goat'+'island') in the Hellenistic period and still 'Sigilio' in late Medieval times). Both discussion with local inhabitants today and the evidence of the 1840 census (see below) suggest that the provision of small livestock herds was also a strategy used at the family scale to provide some independence for young couples before they were able to buy or inherit land, as well for widows living alone.

\section{Landscape Archaeology}

The 1840 census is particularly informative. In addition to the names and ages of all inhabitants, their village domicile and family livestock holdings were also recorded. Figure 4 therefore maps the approximate location of the 68 recorded households and 280 individuals, said to be domiciled in ten or so different parts of the island, as well as their holdings. The overall impression is of small group of multi-family communities with a mixed arable and 
livestock strategy in most cases, and only a few wealthier extended families (with both more land and livestock). Potamos as the main harbour area stands out as more demographically diverse, as one might expect, and this is corroborated by the wider range of stated occupations for people living there and more households without livestock.

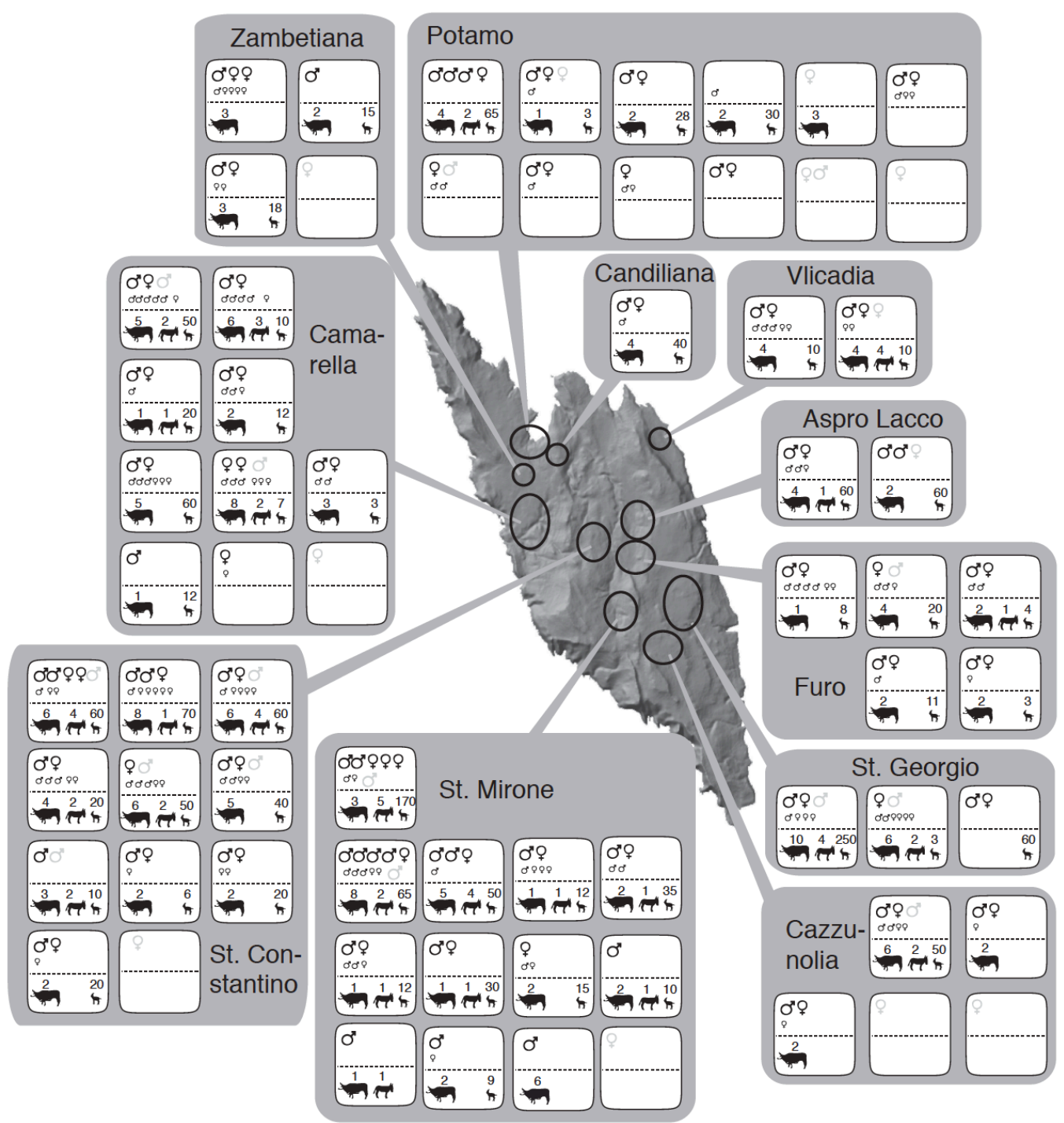

Figure 4. A distribution map of the households and livestock that were recorded in the 1840 census of Antikythera. The place-names (as written in the census) are those declared as household domiciles (the location of 'Furo' is uncertain). The livestock categories are cattle, donkeys and undifferentiated sheep/goat. Smaller symbols are used for those who are unmarried and under 18 years old, grey symbols for people over 50 years old (TNA C0136.1339). 
Standing buildings, gravestones and infrastructure ruins provide a complementary and important source of information about 19th and early 20th century human activity on Antikythera (figure 5). Here we can extend some insights provided by an intensive archaeological landscape survey of Antikythera, ${ }^{37}$ which included considerable attention to physical remains of the 19th and earlier 20th century. What does this physical evidence for village life tell us at the island scale and how does it relate to archival insights about households? First, it is worth noting that the cemetery evidence indicates episodes of nucleated burial grounds as early as the Bronze Age, and then with further visible episodes in the Hellenistic and Late Roman periods. As on Kythera and elsewhere in Greece, ${ }^{38}$ Antikytherans were not obviously buried with monumentalised, family-named grave markers until quite late (with several small cemeteries developing next to the island's main churches by late $19^{\text {th }}$ century), meaning that we cannot infer much from the surname distributions on gravestones or ages-at death until the later 20th century.

In contrast, patterns of nucleation and dispersal of house architecture is more informative. Today the island exhibits standing remains of at least 250 houses in traditional pre-concrete materials (or with evidence of this early phase beneath modern renovations) as well as 125150 more isolated field shelters whose functions might range from permanent habitation to seasonal dwelling to crop/tool storage and/or animal cover. It seems likely that these structures mostly post-date the initial recolonisation phase in the late 18th century (where occasional references in early documents point to both less permanent constructions and some dwellings partially cut into cliff faces) and are mostly from the 19th and earlier 20th centuries. The latter dating was in several instances confirmed by discussion with local residents. These identifiable older houses cluster loosely into hamlet groups and have often been given names referring to the founding family's surname, but it is interesting that only the two largest, the port community at Potamos and the inland village at Agios Myronas (aka Galaniana, or 'St Mirone' in Figure 4), exhibit the denser clustering of houses found in many other Greek island contexts. These naming conventions, the sequence of architectural 
forms for adjacent buildings, 19 th-early 20 th century surface pottery ${ }^{39}$ nearby and interviews with the island's older inhabitants all suggest that very localised sequences of houses were rebuilt, occasionally by the same couple and nuclear family unit, but mostly reflect a very limited, short-distance neolocality in which a newly-wed couple constructed a separate dwelling within the same overall family micro-region.

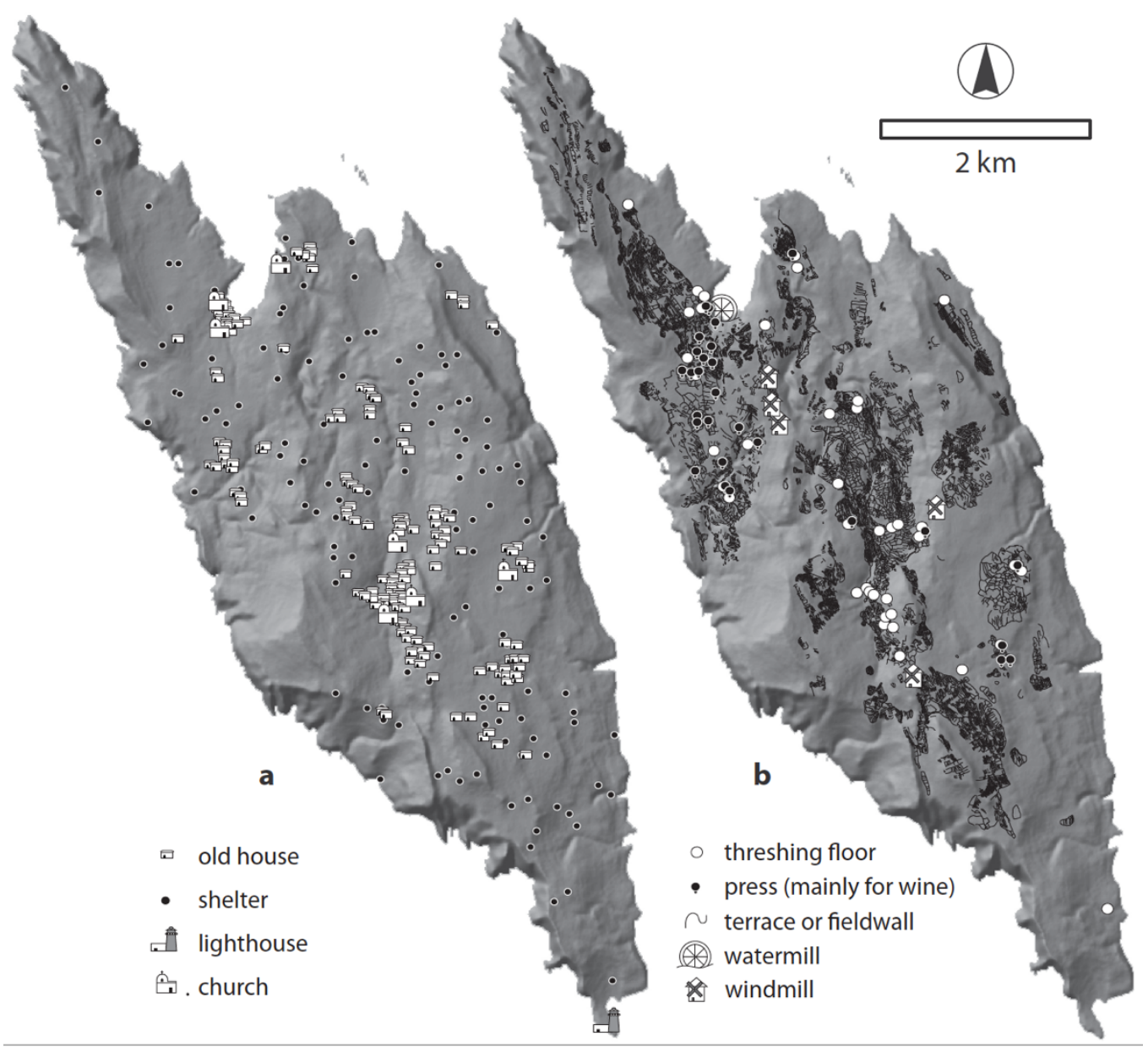

Figure 5: Island-wide distributions from 19th and early 20th century period: (a) standing buildings (N.B. newer houses built in concrete have been excluded, "old house" implies one made in traditional materials and likely to be of $19^{\text {th }}$-earlier $20^{\text {th }}$ century date), and (b) agricultural processing installations and field systems.

Beyond the standing remains of houses there are a series of $19^{\text {th }}$-20th century churches, 5 windmills, a water mill, 30 or more grape presses and over 40 threshing floors, but perhaps the most interesting evidence that exists in abundance beyond the villages are the enclosed field systems and agricultural terraces. There are some 12,000 free-standing or terrace riser 
walls across the island. These structures are a form of landscape capital (investments in the landscape that have consequences over multiple human generations) that visibly cover some 30 per cent of the island and therefore account for the vast majority of the land said to be under crop in peak periods. Behind or below the latest 19th-20th century phases of terracing are also earlier phases of terracing hinting that such investments were intermittent and episodic in a similar way to the population histories with which they were entangled. A key point here is that ethnographic evidence and spatial modelling suggest terracing on the island emerged out of household-scale and hamlet-scale activities in a very agglomerative fashion. While more or less investment in terracing may track coarse-grained population highs and lows over the longer term, the actual construction of these investments at decadal scales occurs in response to a wide range of economic factors, and important among the latter is probably a family cycle that necessitated increased investment in arable land as a precursor or as a desirable accompaniment to new household formation. ${ }^{40}$

\section{Conclusion}

This paper has sought to work at the interface of documentary history and archaeology, both with a view to wider debates in Mediterranean population studies and with regard to the current limitations on how archaeological evidence has been interpreted. In particular, the discussion above has been able to juxtapose a convenient small-island landscape (which offers a rare instance of a landscape that in certain ways has been explored in its entirety) with a passing longer-term eye for the island's cycles of population and depopulation over 7,000 years, and a core shorter-term focus on the most recent episode of island settlement. By drawing inspiration from the detail of the census and other $19^{\text {th }}$ century records, but also by combining further strands of evidence, we can much better understanding, for instance, of the likely importance of migratory work for the island or of archaeologically-observed terraced cultivation as the likely result of a cycle of investment and household formation. Similarly, patterns of livestock ownership, though patchy, are occasionally sufficient to 
highlight how small ovicaprid herds maintained at the household level might also be a further investment strategy linked to family cycles.

The discussion above has also tracked probable demographic and economic changes within the period covered by the documentary evidence. Agricultural records show changing ratios of goats to other livestock that seem in inverse proportion to human community size. In the period of higher population and good census data during the earlier $9^{\text {th }}$ century, it is also possible to suggest increasing female engagement with regional 'circulatory' employment opportunities and non-participation in family formation. We get further insight from these records about the impact of the 1820s Aegean refugee crisis on a small, under-resourced island on a geopolitical frontier. Perhaps surprisingly, given prevailing narratives on migration in the present day, the arrival of nearly a thousand refugees (on an island with a more stable contemporary population of one-quarter that number) leaves no longer-term trace in either the landscape or the demographic structure of Antikythera as far as we can see. This is an subject that clearly merits much further research in order to understand if the unusually difficult conditions of life on Antikythera have rendered an equally unusual result, or if this is in fact a typical outcome of crisis migration.

The above characterisation of the pre-modern demography of the island also raises several questions about the consistency and continuity (or not) of demographic regimes across wider swathes geographic areas such as Greece or the Mediterranean. The apparent $19^{\text {th }}$ century Antikytheran pattern of loosely clustered villages on the one hand, and frequent short-distance neolocality on the other, provides an important twist on simple stay-or-leave models of marital residence, and raises questions about how census takers might handle the recording of co-residential couples under the same roof and/or using the same cooking spaces, couples living in houses next to each other but potentially sharing land, food preparation, activities, etc. and more clear-cut separation of such units by larger distances and across all household functions. ${ }^{41}$ Without mutually-supportive insights from multiple 
categories of evidence covering multiple periods, including ethnographic identification of toponyms and household buildings, reconstruction of land holding units and livestock holding, residency information, and census data, we arguably only get only a skewed perspective of the structure of new communities and their re-colonisation of an abandoned island. In any case, the unusual nature of the collected data from Antikythera allows us to glimpse a highly dynamic population pattern, characterised by episodes of near complete island abandonment and routine off-island mobility, with important consequences for physical island infrastructure, household co-location, agricultural and pastoral practice and on-island family structure.

\section{Acknowledgements}

This paper builds on work first conducted by the Antikythera Survey Project and we are particularly grateful to ASP co-directors James Conolly, for comments on a draft of this paper, and Aris Tsaravopoulos, for all of his help over many years. We would also like to thank John Bennet, Stratos Charchalakis, Deborah Harlan, Eleni Harou and Anna Stellatou for help and advice with archival sources in both the UK National Archives and Kythera Historical Archive, and Jennifer Copithorne and Siriol Davies for assistance with Italian vocabulary. Special thanks to Sarah Livesey for her assistance in transcription. Joanita Vroom, Charles Frederick, Sue Colledge and Carole Palmer are further colleagues whose previous work on recent periods of Antikytheran archaeology have informed the discussion here. On Antikythera, a general thanks is due to the island community for support and welcome over many years, and during a visit devoted to this particular paper, especially to Andreas Charchalakis, Nick Politis and Sofia Politis. We are also indebted to the journal reviewers and editor for considerable useful advice. 


\section{Endnotes}

${ }^{1}$ For example: Herzfeld, M. 1980. Honour and shame: problems of the comparative analysis of moral systems, Man 25: 339-351; de Pina-Cabral, J. 1989. The Mediterranean as a category of regional comparison: a critical view, Current Anthropology 30: 399-406; Purcell, N. 2003. The boundless sea of unlikeness? On defining the Mediterranean, Mediterranean Historical Review 18.2: 9-29; Viazzo, P.P. 2003. What's so special about the Mediterranean? Thirty years of research on household and family in Italy, Continuity and Change 18; 111-137; Albera, D. 2006. Anthropology of the Mediterranean: between crisis and renewal, History and Anthropology 17.2: 109-133; Chambers, I. 2008.

Mediterranean Crossings: The Politics of Interrupted Modernity, Durham, NC: Duke University Press. ${ }^{2}$ Hajnal, J. 1965. European marriage pattern in historical perspective, in D.V. Glass and D.E.C. Eversley, (eds.) Population in History, London: Arnold.

${ }^{3}$ For example, via case studies in Laslett, P. and R. Wall 1972 (eds.) Household and Family in Past Times, Cambridge: Cambridge University Press.

${ }^{4}$ Viazzo 2003. Continuity and Change 18

${ }^{5}$ Kertzer, D.I. 1995. Household history and sociological theory, Annual Review of Sociology 17: 155179.

${ }^{6}$ Ruggles, S. 2009. Reconsidering the Northwest European family system: living arrangements of the aged in comparative historical perspective, Population Development Review 35.2 : 249-273

${ }^{7}$ Reher, D.S. 1998. Family ties in western Europe: persistent contrasts, Population and Development Review 24.2: 203-234. Viazzo 2003. Continuity and Change 18.

${ }^{8}$ pp 3-4, Goody, J. 1996. Comparing family systems in Europe and Asia: Are there different sets of rules?, Population and Development Review 22: 1-20.

${ }^{9}$ See Valaoras, V.G. 1960. A Reconstruction of the Demographic History of Modern Greece, The Milbank Memorial Fund Quarterly 38.2: 115-139; and for an excellent recent overview: Hionidou, V. 2016. Historical demography of Greek populations, in Fauve-Chamoux, A., Bolovan, I. and Sogner, S. (eds.) A Global History of Historical Demography: Half a Century of Interdisciplinarity: 291-300. Bern: Peter Lang.

${ }^{10}$ Valaoras 1960 The Milbank Memorial Fund Quarterly 38.2; Hionidou V. 1998. The adoption of fertility control on Mykonos, 1879-1959: Stopping, spacing or both?, Population Studies 52.1: 67-83; Gavalas, V.S. 2008. Island mortality in the past: some evidence from Greece, Journal of Biosocial Science 40: 203-222.

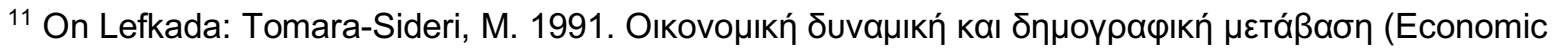

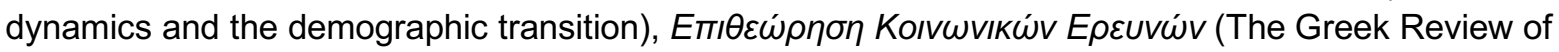
Social Research) 80: 70-85; on Mykonos: Hionidou 1998. Population Studies 52.1; on Paros: Gavalas 2008 Journal of Biosocial Science.

${ }^{12}$ Caftanzoglou, R. 1997. Shepherds, innkeepers, and census-takers: the 1905 census in two villages in Epirus, Continuity and Change 12.3: 403-424.

13 The links between inheritance patterns in different parts of Greece and marriage are discussed in Petmezas, S. and E. Papataxiarchis 1998. The devolution of property and kinship practices in lateand post-Ottoman ethnic Greek societies. Some demo-economic factors of 19th and 20th century transformations, Mélanges de l'Ecole Française de Rome. Italie et Méditerranée 110.1: 217-241, and in the Ionian's the discussion in Couroucli, M. 1985. Les Oliviers du Lignage. Une Grèce de Tradition Vénitienne. Paris: G.-P. Maisonneuve et Larose is relevant although Corfiote inheritance patterns in the Venetian period relate in part to the island's particularly strong monoculture in olive.

${ }^{14}$ Hionidou, V. 1995. Nuptiality patterns and household structure on the Greek island of

Mykonos, 1849-1959, Journal of Family History 20.1: 67-102.

${ }^{15}$ Forbes, H. 2009. Researching Ekina ta Khronia [Times Past] in a Rural Greek Community, Public Archaeology: Archaeological Ethnographies 8.2-3: 88-107.

${ }^{16}$ Sant Cassia, P. and C. Bada 1992. The Making of the Modern Greek Family: Marriage and

Exchange in Nineteenth-Century Athens, Cambridge: Cambridge University Press.

${ }^{17}$ Hionidou, V. 2002. "They used to go and come"? A century of circular migration from a Greek island, Mykonos 1850-1950, Annales de Démographie Historique 104.2: 51-57. See also for an 
Ionian/Cycladic comparison, Gavalas, V.S. 2008. Marriage patterns in Greece during the twentieth century, Continuity and Change 23: 509-529

18 Szoltysek, M. 2015. Households and family systems, Scott, H. (ed.) The Oxford Handbook of Early Modern European History, 1350-1750 I: 313:341. Oxford: Oxford University Press.

${ }^{19}$ See Bevan, A. and J. Conolly 2013. Mediterranean Islands, Fragile Communities and Persistent Landscapes: Antikythera in Long-term Perspective. Cambridge: Cambridge University Press.

${ }^{20}$ For a general overview of the political situation in Greece of the period covered by this paper, see Woodhouse, C.M. 1991. Modern Greece. A Short History, London: Faber and Faber, pp122-175, and for more detailed discussion of the contemporary political climate on Kythera (and Antikythera), see Leontsinis G.N. 1987. The Island of Kythera. A Social History, Athens: Saripolos. pp109ff. An important contemporary British period source with brief discussion of marriage and households is Kendrick, T.T.C. 1822 The Ionian Islands: Manners and Customs, London: James Haldane, especially pp81-91.

${ }^{21}$ For example: Leontsinis G.N. 1987. The Island of Kythera. A Social History, Athens: Saripolos;

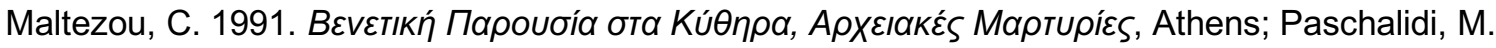
2009. Constructing Ionian Identities: The Ionian Islands in British Official Discourses; 1815-1864 (PhD dissertation, University College London); Hionidou V. 2015. From modernity to tradition: households on Kythera from the early 19th century, in Sovic, S., Thane, P. and P. Viazzo (eds.): 47-68. S. Sovic, P. Thane, P. Viazzo eds., (2015) The History of Families and Households: Comparative European Dimensions, Leiden: Brill.

22 There are also as yet under-appreciated series of records associated with the sanitation centre on the island (and for neighbouring Kythera), that preserve important health and mortality information, albeit patchily.

${ }^{23}$ The exact date for this early census not directly given on the document, but is very likely to fall between 1811 and 1814 on the basis of several forms of evidence. First, the handwriting is consistent with land and animal tax documents from 1811-1814 (the animal count of May 1814 which is likely to be the same recorder), and there are no clear tax, BMD or census documents in the archive earlier than 1811. Statistical comparison of the ages of men that clearly appear in both this and the 1840 census also suggests an average difference of 27 years.

${ }^{24}$ Berkner, L. 1972. The stem family and the developmental cycle of the peasant household: An eighteenth century Austrian example, The American Historical Review 77.2, 398-418.

25 The archaeological record suggests low level activity on Antikythera in many periods, so it may well be that there were several episodes of attempted recolonization before the late $18^{\text {th }}$ century, but with little chance of being sustained until the altered security conditions of the start of the $19^{\text {th }}$ century. The island is mentioned as unpopulated and uncultivated in the 1715 Ottoman defter of Kythera: see Kiel, M. 2007. The smaller Aegean Islands in the 16th-18th Centuries according to Ottoman administrative documents, in Davies, S. and J.L. Savis (eds) Between Venice and Istanbul: Colonial Landscapes in Early Modern Greece: 35-54. Athens: The American School of Classical Studies at Athens); Balta, E.

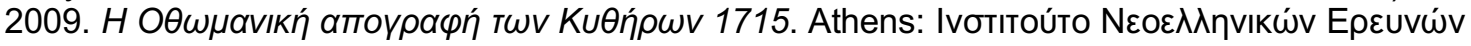

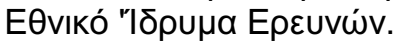

${ }^{26}$ On a larger sample, it would be perhaps useful to attempt estimates of fertility based on the 'own children' method (e.g. Scalone, F. and M. Dribe 2016. Testing child-woman ratios and the ownchildren method on the 1900 Sweden census: Examples of indirect fertility estimates by socioeconomic status in a historical population, Historical Methods: A Journal of Quantitative and Interdisciplinary History 50.1: 16-29), but we have decided not to do so here given the small size of the overall population.

${ }^{27}$ Hammel, E.A. and Laslett, P. 1974. Comparing household structure over time and between cultures, Comparative Studies in Society and History 16.1: 73-110.

${ }^{28}$ Ruggles, S. 2009. Reconsidering the Northwest European family system: living arrangements of the aged in comparative historical perspective, Population Development Review 35.2: 249-273

29 Hionidou, V. 2002 Annales de Démographie Historique 104.2

${ }^{30}$ See also pp 202-203, Leontsinis G.N. 1987. The Island of Kythera. A Social History, Athens:

Saripolos.

${ }^{31}$ Hionidou, V. 2002 Annales de Démographie Historique 104.2

${ }^{32}$ Although we have not come across evidence for Antikythera specifically, it is worth noting that further means of financial improvement and geographic mobility for 19th century females from the 
Ionian islands was prostitution, with for example evidence for Kytherans working in this profession in Hermoupolis where $45 \%$ of the prostitutes came from the lonian islands (Dritsas 2002: 24, 69).

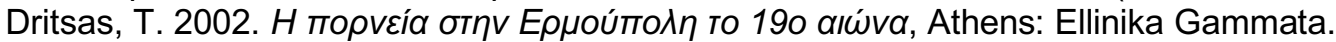

${ }^{33}$ For example,. a letter mentioning the crisis by Antikythera's chief of police in 1824, TNA CO136.1334, see also Leontsinis 1987: 190-192.

${ }^{34}$ Frangakis-Syrett, E. 1994. Monoculture in nineteenth-century Greece and the port of Patras, Journal of the Hellenic Diaspora 20.2: 9-34.

${ }^{35}$ See Hionidou, V. 1. Nineteenth-century urban Greek households: the case of Hermoupolis, 18611879, Continuity and Change 14: 403-427.

${ }^{36}$ For British efforts to expand agricultural land, see Leonitsinis 1987: 217-41. The lonian islands present a potentially bewildering range of historical weights and measures, with further variation due to changing preferences from the end of the Venetian Republic through into the period of British administration and union with the independent Greek state. For early records ca.1811-1814, family land parcels are referred to in misure. The lonian misura could be both a dry capacity/weight measure and a unit of land area. As far as we can judge, it is the latter land area unit which is meant in the documents, and contemporary manuals (e.g. Waterston 1840: 165) suggested that 1 misura of land = 0.3 ha. A different unit, the squela, was sometimes used in the Antikytheran records for smaller parcels of non-arable cultivation (particularly vineyards) and it appears that 6 squele (aka 6 zappade) $=1$ misura. These are the assumptions behind the land calculations in figure 4b. For later records from 1820s onwards, the final administrative documents use Imperial units and clearly distinguish annual volumetric production (e.g. in bushels) from measures of total land-holding (in acres), although there is clearly both some rounding of these statistics and occasionally suggestions for carry-over of less important statistics from year to year. Waterston, W. 1840. A Manual of Commerce, Edinburgh, Oliver and Boyd.

${ }^{37}$ The survey was conducted in 2005-2007 with the raw data published in full as Bevan, A. and J. Conolly 2012. Intensive survey data from Antikythera, Greece, Journal of Open Archaeology Data 1.1 (doi:10.5334/4f3bcb3f7f21d), and for wider discussion of results, see Bevan and Conolly 2013 Mediterranean Islands.

${ }^{38}$ Tzortzopoulou-Gregory, L. 2010. Remembering and forgetting: the relationship between memory and the abandonment of graves in nineteenth- and twentieth-century Greek cemeteries, International Journal of Historical Archaeology 14.2: 285-301. For an exception, see Anastasopoulos, A. 2008. The Islamic gravestones of Ottoman Rethymno. Preliminary remarks and thoughts about them, in Antonis Anastasopoulos (ed.), The Eastern Mediterranean under Ottoman Rule: Crete, 1645-1840. Halcyon Days in Crete VI. A Symposium Held in Rethymno, 13-15 January 2006, Crete University Press, 317329.

${ }^{39}$ For discussion of this surface pottery, see Bevan and Conolly 2013. Mediterranean Islands, Fragile Communities and Persistent Landscapes pp72-73,85-111.

${ }^{40}$ Bevan, A., J. Conolly, S. Colledge, C. Frederick, C. Palmer, R. Siddall and A. Stellatou 2013. The Long-Term Ecology of Agricultural Terraces and Enclosed Fields from Antikythera, Greece, Human Ecology 41: 255-272.

${ }^{41}$ This is also noted for 18th century Kythera via notarial records by Hionidou V. 2011. Independence and interdependence: Household formation patterns in eighteenth century Kythera, Greece, The History of the Family 16.3: 217-234; Hionidou V. 2015. From modernity to tradition: households on Kythera from the early 19th century, in Sovic, S., Thane, P. and P. Viazzo (eds.): 47-68. It has also been asserted to be unusually common in southern Europe more generally by Augustins: pp343-347, Augustins, G. 2002. The perpetuation of families and the moulding of personal destinies, in D.I.

Kertzer and B. Barbagli Marzio (eds.), The History of the European Family 2: 322-347. New Haven: Yale University Press. 
Table 1. A Hammel-Laslett classification of resident household structure from nominal censuses for 1814, 1840 and 1845, and a rough approximation of the same for both residents and refugees from a simpler register in 1825.

\begin{tabular}{|c|c|c|c|c|c|c|c|}
\hline Class & Description & $\begin{array}{c}\sim 1814(\%) \\
n=42)\end{array}$ & $\begin{array}{c}1825 \text { Refugees } \\
(\%, n=226)\end{array}$ & $\begin{array}{c}1825 \\
\text { Residents } \\
(\%, n=52)\end{array}$ & $\begin{array}{c}1840(\%, \\
n=66)\end{array}$ & $\begin{array}{c}1845 \\
(\%, \\
n=74)\end{array}$ & $\begin{array}{l}\text { change } \\
\text { from } \\
\sim 1814 \text { to } \\
1845\end{array}$ \\
\hline 1 & Solitaries & 2.38 & 0 & 0 & 0 & 1.35 & -1.03 \\
\hline 1a & widowed & 0 & 0 & 0 & 12.12 & 1.35 & 1.35 \\
\hline 1b & single/unknown & 7.14 & 3.10 & 0 & 9.09 & 5.41 & -1.74 \\
\hline 2 & No family & 0 & 0 & 0 & 0 & 0 & 0 \\
\hline $2 \mathbf{a}$ & Coresident siblings & 0 & 0 & 0 & 0 & 2.70 & 2.70 \\
\hline 2b & Coresident relations of other kinds & 0 & 0 & 0 & 0 & 2.70 & 2.70 \\
\hline 2c & Persons not evidently related & 0 & 0 & 0 & 0 & 0 & 0 \\
\hline 3 & Simple Family Households & 0 & 0 & 0 & 0 & 0 & 0 \\
\hline $\mathbf{3 a}$ & Married Couples Alone & 11.90 & 7.52 & 9.62 & 6.06 & 2.70 & -9.20 \\
\hline 3b & Married Couples w child/children & 64.29 & 13.27 & 11.54 & 57.58 & 62.16 & -2.12 \\
\hline 3c & Widowers with children & 7.14 & 1.77 & 3.85 & 3.03 & 8.11 & 0.97 \\
\hline 3d & Widows with children & 7.14 & 50.44 & 65.38 & 7.58 & 5.41 & -1.74 \\
\hline 4 & Extended family households & 0 & 0 & 0 & 0 & 0 & 0 \\
\hline $4 a$ & Extended upwards & 0 & 0 & 0 & 1.52 & 4.05 & 4.05 \\
\hline 4b & Extended downwards & 0 & 0 & 0 & 0 & 1.35 & 1.35 \\
\hline 4c & Extended laterally & 0 & 0 & 0 & 1.52 & 1.35 & 1.35 \\
\hline 4d & combinations of $4 a-4 c$ & 0 & 0 & 0 & 1.52 & 0 & 0 \\
\hline
\end{tabular}




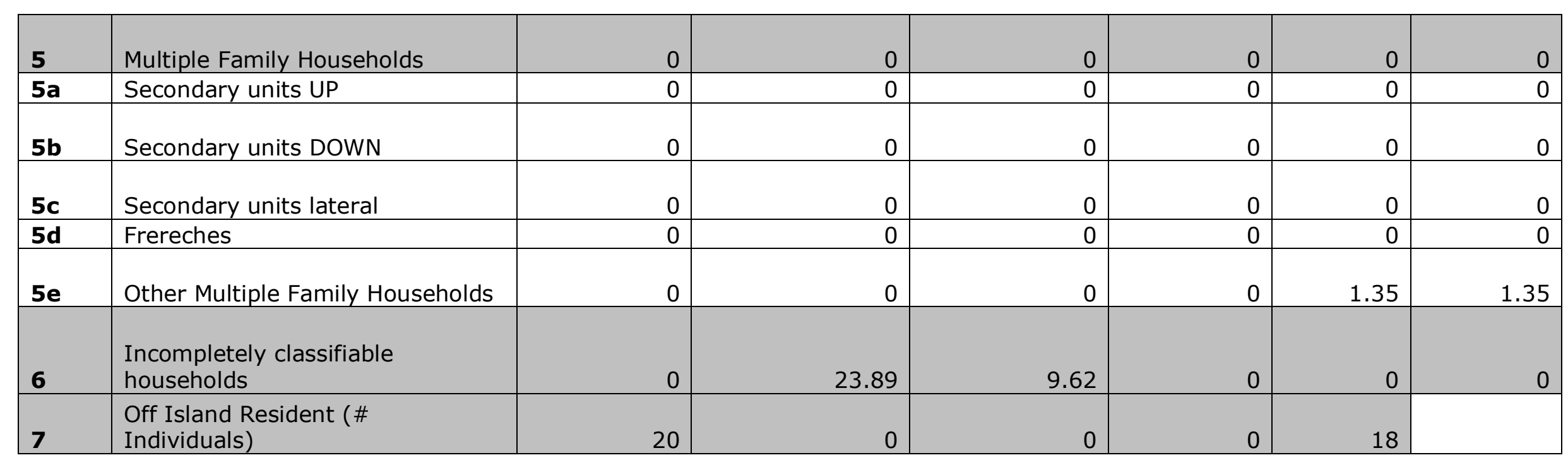

